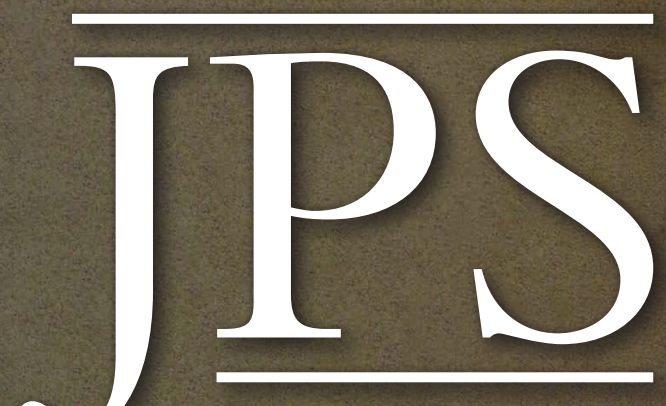

The Journal
of the

Polynesian Society

VOLUME 126 No.2 JUNE 2017

THE POLYNESIAN SOCIETY THE UNIVERSITY OF AUCKLAND NEW ZEALAND
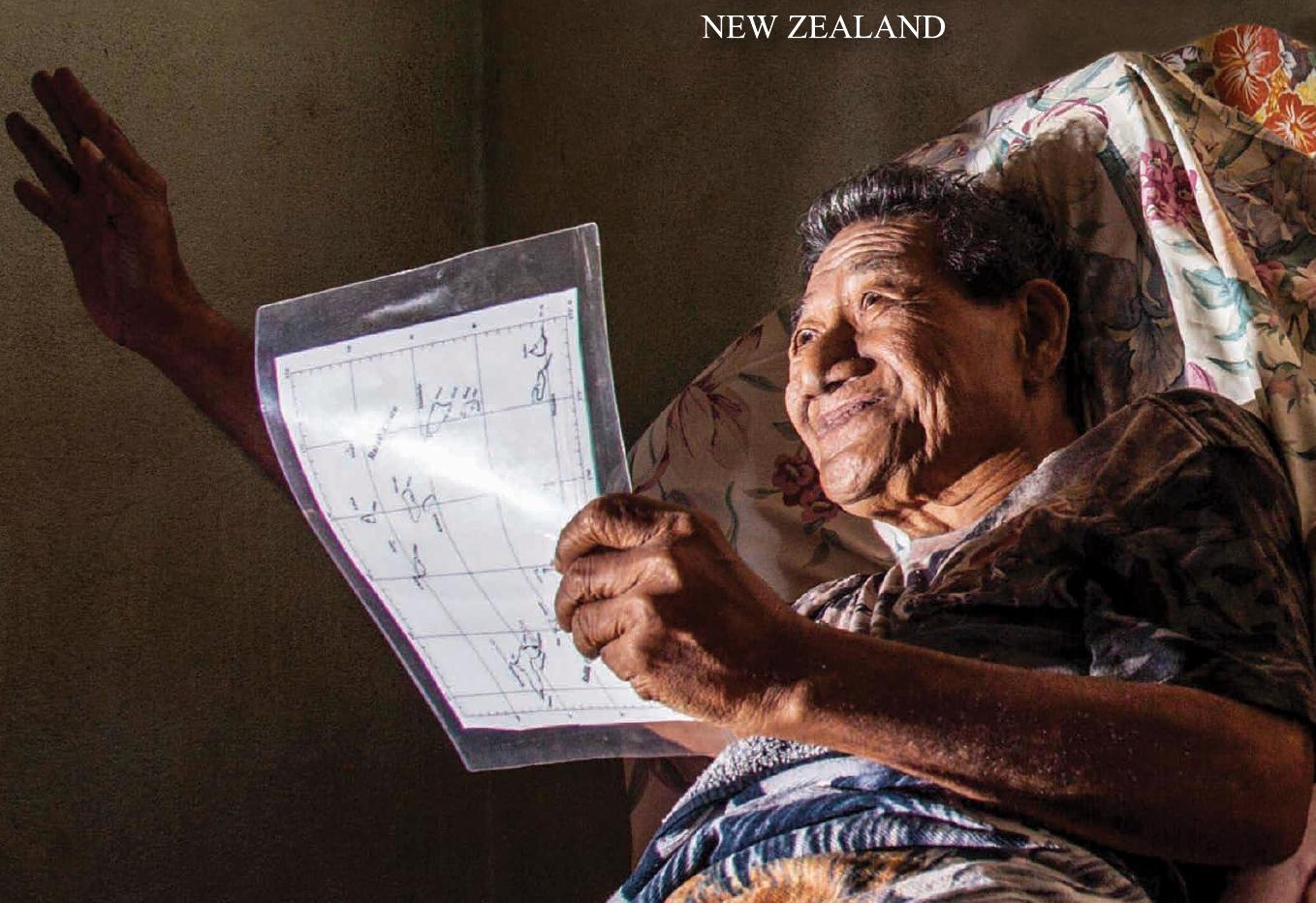


\title{
MĀORI KINSHIP AND POWER: NGĀI TŪHOE 1894-1912
}

\author{
STEVEN WEBSTER \\ University of Auckland
}

Inspired by Eric Wolf's classic Europe and the People Without History (1982), in 1998 I published an essay arguing that between 1840 and 1860 Māori hapu "cognatic descent groups" 'were already changing "not as a whole traditional way of life somehow outside that history, but rather as a whole way of struggle integral to differentiation in capitalism ..." Among the changes detailed, I suggested that some hap $\bar{u}$ were "breaking up into alliances or assimilation with more successful others" or "breaking up in merger with such established class interests as merchants, labour agents, peasants, rural and urban proletariat" (Webster 1998a: 31-32). In these examples I had raised Wolf's conclusion that the power developed by leaders in kin-ordered modes of production influenced by tributary or capitalist colonisation was liable to reach "a limit that can only be surpassed by breaking through the bounds of the kinship order" (Wolf 1982: 94). While the first example may be only a break-up of the kin-order of one hapu to join in the kin-order of anothernot unusual for $h a p \bar{u}$ - the second example can be seen as the more radical historical change that Wolf had in mind: the undermining or immobilisation of the traditional kin-order itself, either by its leaders or by the new forces they are dealing with, or some combination of the two. Wolf later applied his theory of the kin-ordered mode of production to the Kwakiutl, focusing on the role of ideology in political economic power and calling it the "kinordered mode of mobilizing social labor" to stress the inherently social nature of production in Marx's sense (1999: 275; see also 69-131).

I have recently been drawn back to Wolf's insights regarding the forms of power developed by leaders in a kin-ordered mobilisation of social labour, but this time among one particular iwi 'tribe' of Māori: Ngāi Tūhoe. ${ }^{2}$ Although my fieldwork in New Zealand had begun among the Tūhoe in 1972, most of my research had focussed generally upon Māori hapū or ethnic politics (Webster 1975, 1998b, 2002). In 2003, prompted by my unpublished 1984 essay on Tūhoe and the 1921 Urewera Consolidation Scheme (Webster n.d.a), the Waitangi Tribunal asked me to research and report more extensively on that era for their ongoing Urewera investigation. Since then, working in the archival data accumulated in that exciting return to my fieldwork roots, I have now completed two ethnohistorical volumes spanning Tūhoe in colonial history 1894-1926 (Webster n.d.b., n.d.c). The first volume deals with the investigation and establishment of the Urewera District Native Reserve 
(UDNR) 1894-1912, and the second volume is a revision of my report for the Waitangi Tribunal on the subsequent Crown purchasing campaign and Urewera Consolidation Scheme (UCS) 1915-1926 (Webster 2004).

Together, these two volumes examine the negotiated establishment by Tūhoe, supported by statute and a Crown commission, of virtual home-rule over the Urewera District Native Reserve (Figs 1,2) — and its subsequent betrayal by the Crown. Just over a century later, this betrayal and the earlier unjustified confiscation of their coastal lands has been admitted by the Government and redressed by the Te Urewera Act of 2014, returning to the Tūhoe a new form of hopeful home-rule over the extensive mountains and valleys of what was previously the Urewera National Park (Tūhoe Claims Settlement Act 2014, Te Urewera Act 2014).

The first part of the volume dealing with the earlier period 1894-1912 examines the negotiation of the 1896 UDNR Act (The Urewera District Native Reserve Act, 1896) between Tūhoe leaders and Prime Minister Seddon; the procedures and legitimacy among Tūhoe of the UDNR Commission, which was largely under the control of Tūhoe commissioners (and the amateur ethnologists Percy Smith as chairperson and Elsdon Best as secretary); the difficulties the Commission encountered in laying out the reserve into 34 blocks in the name of particular hap $\bar{u}$ with relative shares of ownership among particular descent groups; and a detailed examination of one large hap $\bar{u}$ branch headed by the war-leader Tamaikoha regarding its organisation in sibling groups, marriages and hapu affiliations. My primary objective in this ethnohistory, as it has been since my earliest publication on the Māori in general, is to understand the structure and organisation of hap $\bar{u}$ as cognatic descent groups. I had planned to conclude this volume with one or two chapters attempting to understand hap $\bar{u}$ "clusters" (Ballara 1995) among Tūhoe at this time by examining a few of ten proposed groupings or amalgamations of the 34 blocks of the reserve (Fig. 3). These ten amalgamated titles were suddenly proposed in May at the end of the 1902 season, but aborted (probably by the Native Minister) when the Commission reconvened the following October for its final deliberations. Although neither the proposal nor its withdrawal were satisfactorily explained, it is clear that Tūhoe leaders supported or even proposed it. In anticipation of fulfilling it, the 1901 survey plan had even been modified accordingly.

However, improvement of my method to reconstruct descent group genealogies including spouses, especially by cross-indexing Elsdon Best's 130-page genealogical census of Tūhoe (1898) enabled me to stumble upon two strikingly extensive marriage alliances between four or five descent groups in two of these proposed amalgamations: Parekohe at the north end of the reserve (amalgamating seven blocks; see Fig. 3) and Ruatāhuna- 


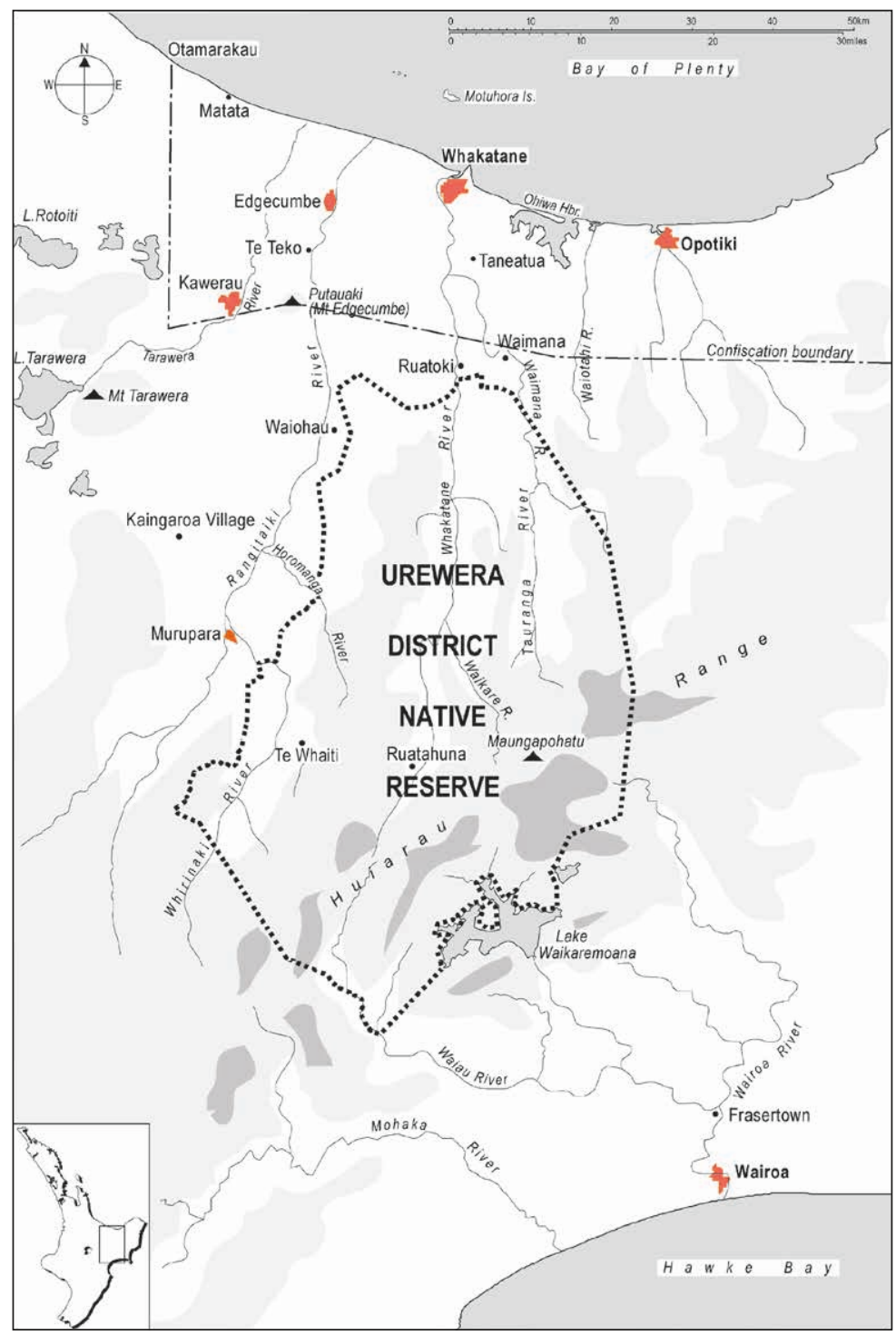

Figure 1. Location of Urewera District Native Reserve (1907) and its vicinity on the North Island, New Zealand. Source: Webster 2004: 13. 


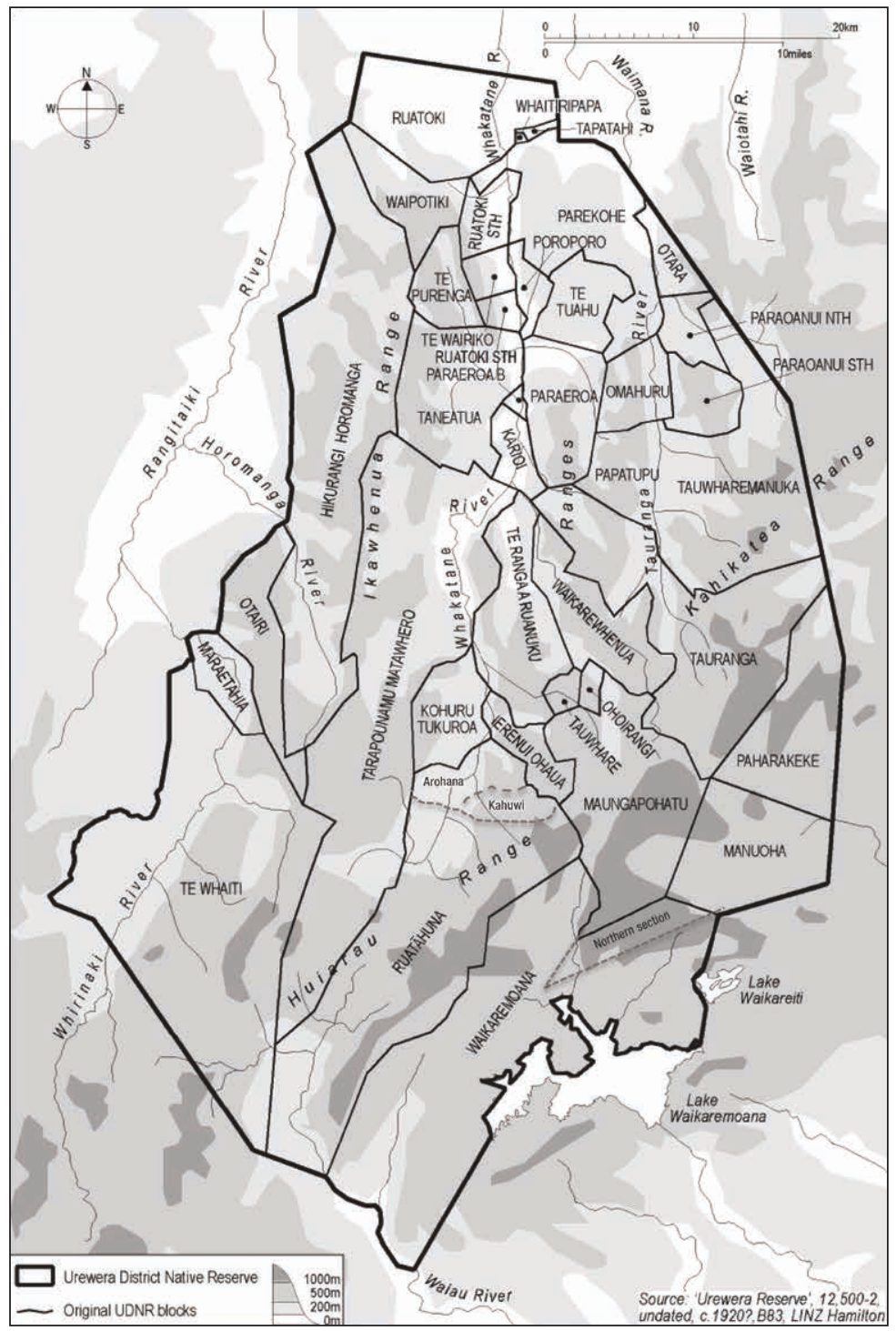

Figure 2. Urewera District Native Reserve showing topography and original blocks (1907). 
Steven Webster 149

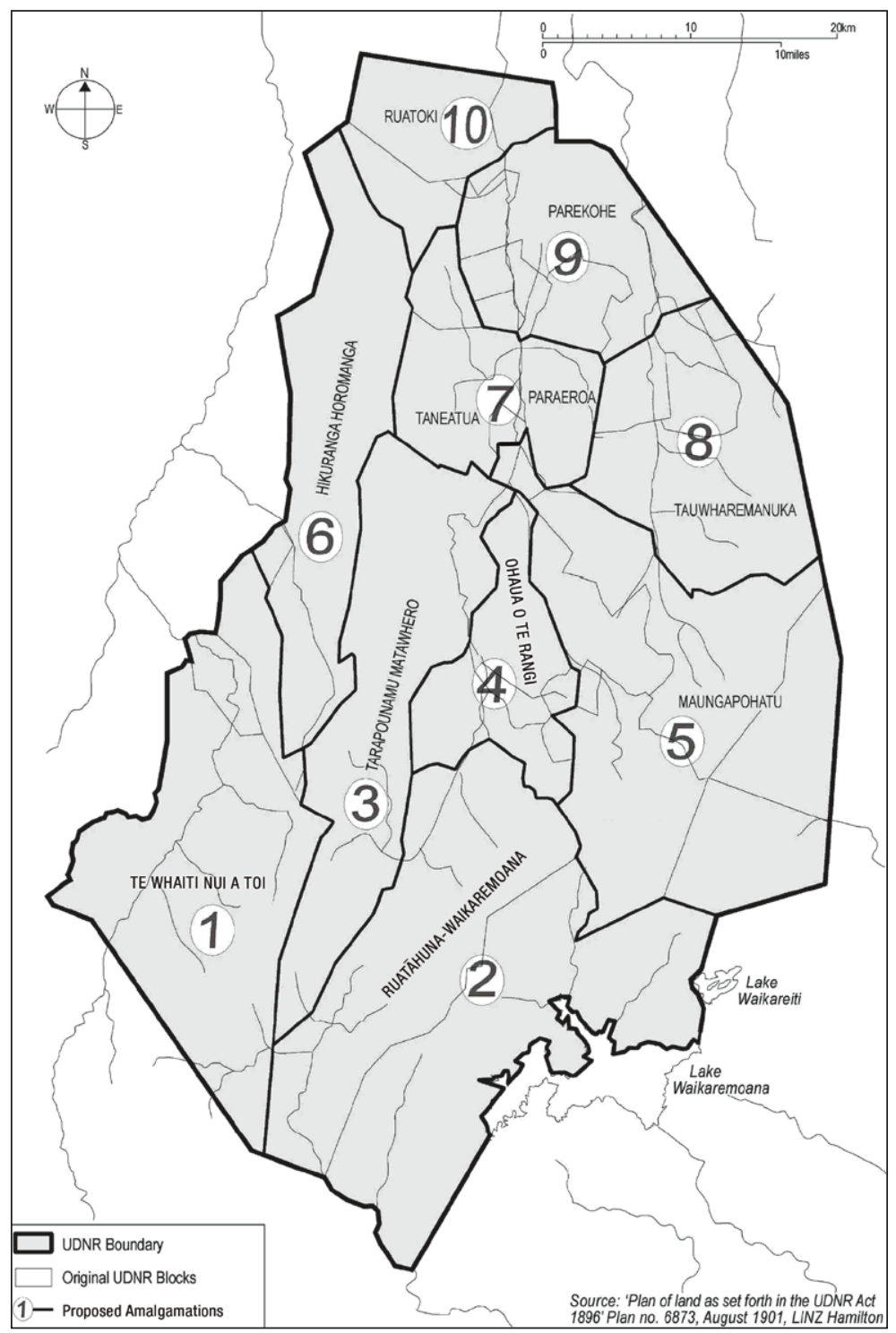

Figure 3. Proposed amalgamations of Urewera District Native Reserve blocks (1902). 
Waikaremoana at the south end (amalgamating two large blocks). In each of the two cases, there were seven or eight intermarriages between a few sibling groups in one generation, four or five in the next, and two or three in the third generation: clearly a growing alliance between hap $\bar{u}$ or hap $\bar{u}$ branches pursued over a half-century. A diagram depicting the intermarriage of five descent groups in the proposed Ruatāhuna-Waikaremoana amalgamation is presented here (Fig. 4). The regular decrease of intermarriages was probably because the increasing solidarity of the alliance was slowed by widening overlap of ancestry and consequent incest restrictions. ${ }^{3}$ Also in each case, the marriage alliance was consistent with historical events that may have motivated them: land lost through Crown confiscation in the $1860 \mathrm{~s}$, and continuing migrations following a Tūhoe "conquest" of Waikaremoana in the early 1800 s, respectively.

Understanding what I call the Ruatāhuna-Waikaremoana migrant marriage alliance (Fig. 4) and its relationship to three Tūhoe leaders of enduring mana 'prestige' enabled me to gain insights into otherwise opaque confrontations between major descent groups that extended at least from 1900 through 1912. These confrontations alone took several more chapters to unravel and explain. The key leaders and descent groups can be introduced here: Te Whenuanui II, a leader of Te Urewera hapü; Numia Kereru Te Ruakariata, a leader of Ngāti Rongo hapü; Tutakangahau Tapui, a leader of Tamakaimoana hapü; and several leaders of the migrant marriage alliance (underlined names in Fig. 4), many affiliated with Ngāti Ruapani or other Tūhoe hapū.

Preoccupied only to understand the more demonstrable ethnohistorical implications of the extensive documentation of the Commission's investigation, none of this brought me explicitly back to the issue of Wolf's theory of kinship and power that I had applied more generally to Māori in my 1998 essay. However, by the time I had proposed plausible explanations of these confrontations between Tūhoe leaders, their hapu, and the migrant marriage alliance, I realised that it was an exemplary case of kinship and power, and perhaps also of leaders "breaking through the bounds of the kinship order" (Wolf 1982: 94). My realisation led to this essay, a recapitulation of the first volume of my ethnohistory in terms of Wolf's thesis of kinship and power.

Throughout the first volume I focus on the demonstrable implications of the documentary record which, although rich in information, were nevertheless usually focussed narrowly on the work of the Commission. Of course, the cultural, social and especially the sensitive political and economic implications of what was going on behind the public scenes of the Commission's work were usually obscured or even suppressed. In the present essay I have relied upon plausible explanations of gaps and inconsistencies in the documentary record that reveal confrontations and strategies between 
Steven Webster 151
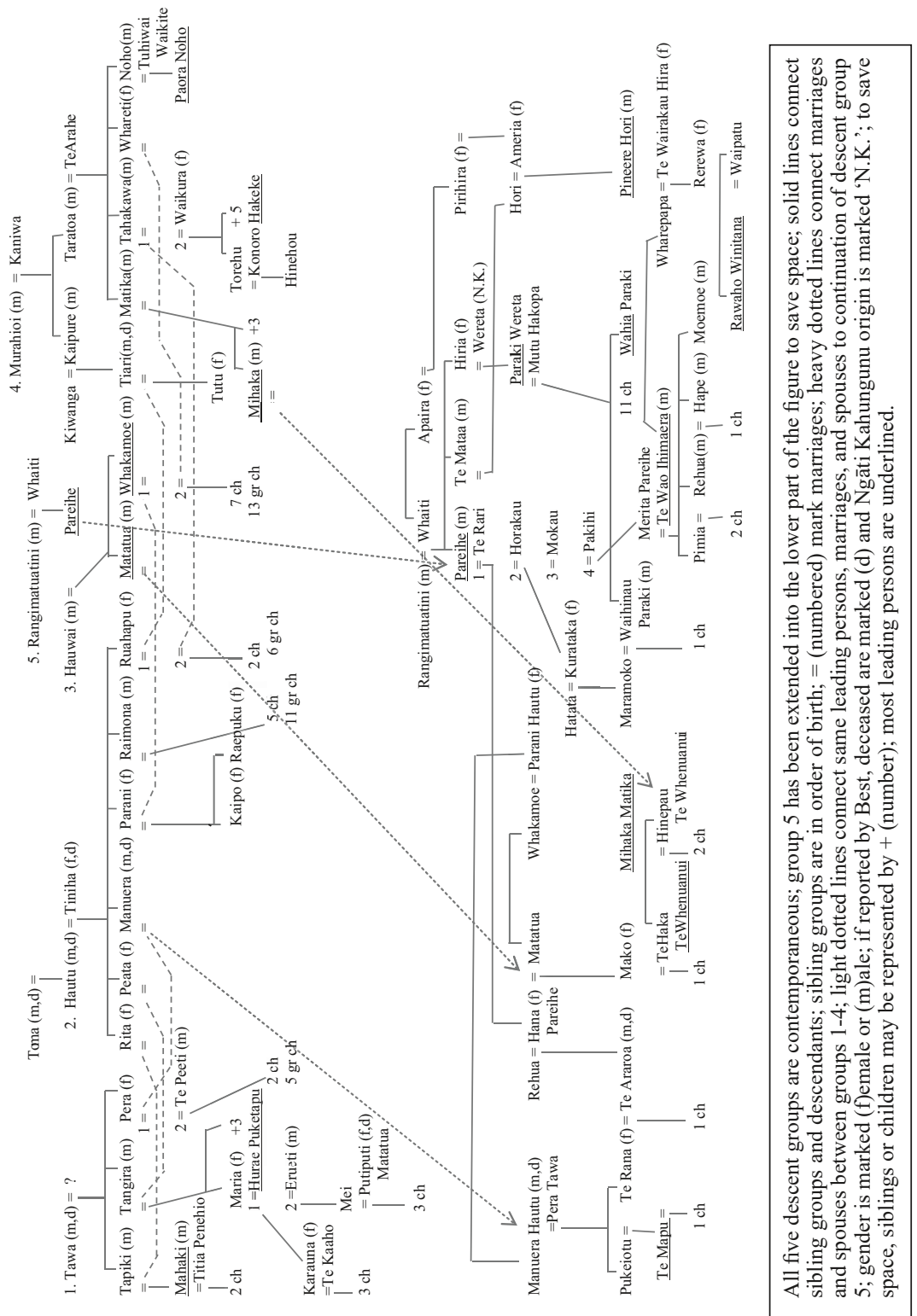

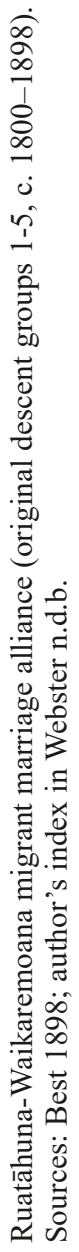

离 
Tūhoe hapu and their leaders operating behind the official scenes of the Commission. I am aware that my conclusions are necessarily tentative, that they will be challenged, and that some will be found to be wrong or misleading. On the other hand, I am reassured by the fact that my approach here is comparable to the search for historical truth the Tūhoe themselves have always pursued. One rangatira 'chief', Hikawera Te Kurapa (a greatgrandson of Te Whenuanui I; see Fig. 5 and Temara 2000), is said to have put their respect for the historical facts this way: "Well ... if you don't tell the truth, it comes back and bites you on the ass."

\section{TŪHOE KINSHIP AND POWER 1894-1912}

Below are telescoped criteria of Wolf's thesis of the kin-ordered mode of mobilising social labour, as it appeared in 1982 (Wolf 1982: 92-96; my selection, ellipses, brackets, and emphases; spelling as in Wolf). He developed it to focus on food-producers rather than food-gatherers, distinguishing the latter in two ways: as tending to expend social labour directly on natural resources rather than transforming them for further use, and inclined to base their kinship simply on filiation and marriage rather than extending it in systems of consanguinity and affinity. Although at the turn of the century Tūhoe straddled this distinction in some ways, they had long been primarily food-producers. By the 1870s they had lost control over their best agricultural lands nearer the coast, due to Crown confiscations in the land wars of the 1860s (Fig. 1). However, they continued to cultivate and herd domestic animals along the remaining valley bottoms extending from the Urewera foothills high into its recesses, as well as hunting and gathering throughout these uplands.

1. In [a food-producing] society, social labor is distributed in social clusters that expend labor cumulatively ... accumulating at the same time a transgenerational corpus of claims and counterclaims [emphasis mine, here and below] to social labor.

2. Where conditions tend toward ecological closure, relations among these clusters need to be more closely defined and circumscribed. ... Under these conditions the idiom of filiation and marriage is used to construct transgenerational pedigrees, real or fictitious. These serve to include or exclude people who can claim rights to social labor on the basis of privileged membership.

3. The "extension" of kinship [in consanguinity and affinity] is therefore not the same as kinship on the level of filiation and marriage [as is typical of gatherers of natural resources]; it is concerned with jural allocation of rights and claims, and hence with political relations between people. ... $[\mathrm{M}]$ arriage ... becomes a tie of political alliance between groups. 
4. [M] anagerial functions [and authority are distributed] unevenly ... whether this be as elders over juniors, as senior over cadet lines, or as lines of higher over lower rank.

5. Such groups are typically equipped with mythical charters defining culturally selected and certified lines of kin connection. ... mythological charters ... allow groups to claim privileges on the basis of kinship ... permit or deny people access to strategic resources.

6. The persistence of the idiom of kinship in the jural-political realm, however, poses a problem... The fact that leaders can rise to prominence in this way constitutes one of the Achilles' heels of the kinship mode. ... For as a chief or other leader draws a following through judicious management of alliances and redistributive action, he reaches a limit that can only be surpassed by breaking through the bounds of the kinship order.

7. [T] hese tendencies toward inequalities ... are greatly enhanced when kin-ordered groups enter into relationships with tributary or capitalist societies. ... Chiefs can ... employ these external resources to immobilize the workings of the kinship order.

8. In practice, the term [chief] was usually bestowed by Europeans upon any native person of influence who was in a position to forward or to hinder their interests.

Tūhoe kinship and power, especially in confrontation with the colonial power of the Crown, is implicit in my ethnohistory of the Crown's betrayal of the UDNR Act in its predatory purchase campaign and subsequent Urewera Consolidation Scheme between 1915-1925, which took more than 70\% of the reserve for the Crown (Webster 2004). However, the earlier investigation of the UDNR occurred under a relatively benevolent administration and, until about 1908, remained largely under control of Tūhoe leaders. Consequently, the kin-ordered mode of mobilising social labour and the political economic power derived from it, between Tūhoe leaders as well as between them and the Crown, is less obvious in the records but can nevertheless be made explicit.

A preview of the following argument suggests that the situation in the Urewera and the UDNR at the turn of the century fits Wolf's thesis closely. The first four criteria above are substantiated especially in the first part of Volume I (Webster n.d.b) examining the difficulties of the Commission defining Urewera blocks by hapu and analysing the social organisation and $h a p \bar{u}$ affiliations of one large and influential hap $\bar{u}$ branch. Substantiation of the last three criteria above can be drawn from the last part of the volume, reconstructing what I described above as the Ruatāhuna-Waikaremoana migrant marriage alliance and its relationship to Tūhoe leaders and their $h a p \bar{u}$. Evidence of criterion 5 dealing with mythological charters of power, 
although only implicit in the records of the Commission, can nevertheless be exemplified. Throughout this recapitulation the power of the Crown, although generally benign, can be seen as integral to the deployment of power between Tūhoe leaders themselves, and finally raises the question of "breaking through the bounds of the kinship order" (criterion 6 above).

The operations of the Crown Commission were intended, by its five Tūhoe commissioners as well as by the 1896 Act and its two Pākehā 'European' members, to focus upon the "jural allocation of rights and claims" (criterion 3) to the Urewera lands. In the second chapter of Volume I discussed the array of Tūhoe leaders, hap $\bar{u}$ identifications by them, and claims and counter-claims to specific areas of land in the name of these $h a p \bar{u}$; the rapid emergence of subordinate descent groups aspiring to independent $h a p \bar{u}$ status; the subordination of some hap $\bar{u}$ or their branches to others in a particular block while dominating in other blocks; and the allocation of relative shares of ownership reflecting these relative rights in different blocks. These descriminations were usually negotiated between Tūhoe themselves, and can be seen as "jural allocation of rights and claims" in hap $\bar{u}$ "clusters" (in sense of Ballara 1995). These will be explored later in terms of the proposed amalgamation of Ruatāhuna and Waikaremoana blocks as well as the relative rights of descent groups within and between blocks.

Although leaders' claims were for areas of land rather than social labour itself, the claims were made in the name of specific hap $\bar{u}$, established or aspiring, with the implication that they could demonstrate recent ancestral occupation or use of the land in question as well as descent from the founding ancestor of that land. The "transgenerational corpus of claims and counterclaims to social labor" (criterion 1) laid before the Commission took the form of oral evidence regarding founding ancestors; whakapapa 'ancestral genealogies'; place names, buildings or their remains; past or continuing occupation or use; rights through conquest or gifting if not by direct ancestry; unchallenged cultivation or hunting and gathering of specific resources from specific locations; and procreation, births, nurturance, marriage, deaths, burials and battles on the land. All this evidence implied the mobilisation of social labour by the claimants or their recent ancestors in the maintenance of these rights.

Again in terms of the criteria drawn above from Wolf, the central jural role of "pedigrees" or whakapapa and oral tradition in adjudication of claims for every part of the Urewera reflected its "ecological closure", just as early colonisation found that every piece of land in New Zealand had previously been claimed by Māori. The jural basis upon which claims would be adjudicated and compromises found was exhaustively and probably independently worked out by the Tūhoe commissioners for Te Waipotiki, the 
first block examined (Fig. 2). The first season's sittings were followed by the chairman's despairing report to Government that, contrary to the misled ideals of the UDNR Act, hapu claims could not simply be aligned with discrete blocks of land but instead overlapped widely throughout the Urewera and were stubbornly contested between claimants. These claimants' whakapapa were accepted or challenged as "real or fictitious", serving "to include or exclude people who can claim rights to social labor on the basis of privileged membership" (criterion 2). Although in the following season of sittings (1900) four of the five Tühoe commissioners agreed to the chairman's resolution to expedite investigations by merging "minor" in "major" claims, the meticulous procedure established for Te Waipotiki continued to be followed. Expedience was actually achieved by routinely deferring to a consensus of Tūhoe leaders settled outside of formal hearings, which were then devoted to unresolved claims, objections or simply to approvals. Although one or another of the five Tūhoe commissioners was officially stood down from cases in which they had claimed an interest, they clearly participated with other Tūhoe leaders in these informal preliminary settlements, as well as behind the scenes in hearings.

The influences of colonial power were more than the benign UDNR Act and its Commission. Although the Tūhoe may have been relatively free of the struggle for control over the social relations of production that had affected Māori nearer urban centres by the time of the 1860s Land Wars, many Tūhoe were directly affected by the struggle for control over Māori land itself (Webster 1998a: 23). The investigation of Te Waipotiki showed that contested ancestral rights had probably been aggravated by the Crown's confiscations of the Tūhoe's more productive agricultural lands to the north, resulting in contested use rights to seasonal foraging that could not be dismissed in favour of occupational rights. By 1890 the operations of the Native Land Court had led to loss of potential Tūhoe rights in other $i w i$ domains, rendering the Urewera "encircled lands" (Binney 2002). By 1900 as many as 10\% of Tūhoe were living outside the UDNR, perhaps many due to the resulting shortage of more arable land. The subordination or demise of some previously established hap $\bar{u}$ (such as Tamaikoha's war-time hapū Ngāi Tama), especially those dependent on the confiscated lands, probably also accelerated the individualisation of social labour as commodities on the local or itinerant market, as well as increasing reliance on trade. The ownership of local retail stores by the war leader Tamaikoha's two senior sons in 1897 indicates that this early integration in the capitalist mode of production had probably been a factor in the development of an "uneven" distribution of "managerial functions" (criterion 4) in the otherwise kin-ordered mode of mobilising social labour.

Details of $h a p \bar{u}$ organisation were examined in terms of one extensive hap $\bar{u}$ branch, the four-generation käwai 'branch' of Tamaikoha, in the Tauwhare 
Manuka block owner list where they appeared most prominently (Webster 2010). In terms of the criteria drawn from Wolf, successful claimant hap $\bar{u}$ appeared in the 1903 provisional block orders as potential or actual social labour under the management or leadership of elders and senior ranks. Block lists for most blocks displayed careful discriminations of uneven status between hapu members, including ranking in each descent group by seniority of generation, sibling birth order including mātämua 'first-born' status by primogeniture and tuakana/teina 'older/younger' status by seniority (both regardless of gender), and seniority between wives and consequently between half-siblings. These rankings were furthermore often recognised to continue through several generations regardless of gender, first-born sibling groups sometimes over-riding the rank of a previous generation of cousins. A descent group's recognised rights varied widely from one to 24 of the 34 blocks in the reserve, reflecting the relative mana of that descent group in each block. Comparison between block lists including the same descent group showed that most block lists were furthermore ranked with regard to the relative mana or status of each descent group recognised to have ancestral and occupational rights in that particular block. As well as ranking the status of a descent group relative to others in a block, the allocation of relative shares within each descent group usually ranged from one to 20 shares per person depending on the generation of the individual or sibling group in the descent group, again regardless of gender.

The strict cognatic descent group structure of hapu or hapu branches (as distinct from whānau or extended families) in the block lists was displayed by the succession of sibling groups or individuals in each generation, while one parent or spouse was usually listed elsewhere in the list or other block lists with their own descent group. The parent through whom the sibling group held their rights in that block appeared separately along with his or her siblings or individually. If the other parent of a sibling group had rights in the same block, their placement in the list usually reflected the differing rank of their descent group in that block, and the shares allocated to their children reflected this advantage or disadvantage. In these manifold ways most block lists consistently served not only, in Wolf's terms, to include or exclude people who can claim rights to social labour on the basis of privileged membership in a given block, but also to rank individuals or sibling groups as well as descent groups according to their differing rights within the block.

Examination of the Tamaikoha descent group was continued with regard to its wider affiliations with hapu and rights that were recognised in other blocks of the UDNR. In Wolf's terms, these affiliations are significant especially in terms of Tamaikoha's and his childrens' relative mana or leadership in the mobilisation of social labour through these $h a p \bar{u}$, for instance in maintaining 
rights to gather from, cultivate, or occupy their various Urewera lands. As indicated by Best's genealogies and the marriages earlier identified, hap $\bar{u}$ affiliations of Tamaikoha's children and grandchildren added by spouses married into the descent group, as well as those gained through his own parents, reflected the potential influence of their leadership in mobilisation of the social labour of innumerable Tūhoe hapu of which ten or fifteen were identified. Evidence of active affiliations drawn from claims submitted, evidence presented, informal as well as formal recognition of leading rights by the Commission, and block committee appointments of its members, indicated that the influence of the descent group had been narrowed in practice (that is, in terms of their own social labour as a hapu branch) to four relatively strong and six relatively weak active affiliations. Divergence or specialisation of hap $\bar{u}$ affiliation was also detected between some of the second generation, specifically Tamaikoha's children by one of his three wives. In contemporary terms, the extent of these affiliations is extraordinary, even given Tamaikoha's personal mana. However, some of these ten hapu were probably actually subordinate to others but were trying to use the opportunity of the UDNR investigation to establish their independence.

The capacity of such ambiguities of hapu affiliation to resolve a stubborn confrontation was illustrated by the compromise between Ngāti Rongo and Te Urewera hapu claims to the coveted Whaitiripapa block just southeast of Ruatoki (Fig. 2). Although Numia Kereru's claim for Ngāti Rongo had earlier been dismissed upon appeal to the Native Land Court, in 1900 before the UNDR Commission it was magnanimously accepted by Tamaikoha, as well as the claims by two closely allied hap $\bar{u}$ apparently arranged by each side as proxy claimants. The whakapapa that Tamaikoha submitted traced descent from a founding ancestor in such a way that most claimants from Ngāti Rongo as well as Te Urewera hapū could be included (Fig. 5; see the descendants of Te Whanapeke extended through Kahuwi on the right side of the genealogy). Award of the block in the name only of Te Urewera hap $\bar{u}$ implied that Numia Kereru had accepted subordination of his hapū to Te Urewera in that block. Insofar as this compromise was stable, it constituted a mobilisation of the combined social labour of these two (or four) hap $\bar{u}$, or at least those branches included in the list of owners, under the newly combined leadership of that block.

On the other hand, the on-going confrontation between these two major $h a p \bar{u}$ in their other branches will be examined more closely later with regard to the Ruatāhuna and Waikaremoana blocks. There, Te Whenuanui II and the migrant marriage alliances' rejection of Kahuwi and assertion of Arohana's exclusive rights for Te Urewera hapu (favouring the left side of Fig. 5) held off the claims of Ngāti Rongo until 1912. 

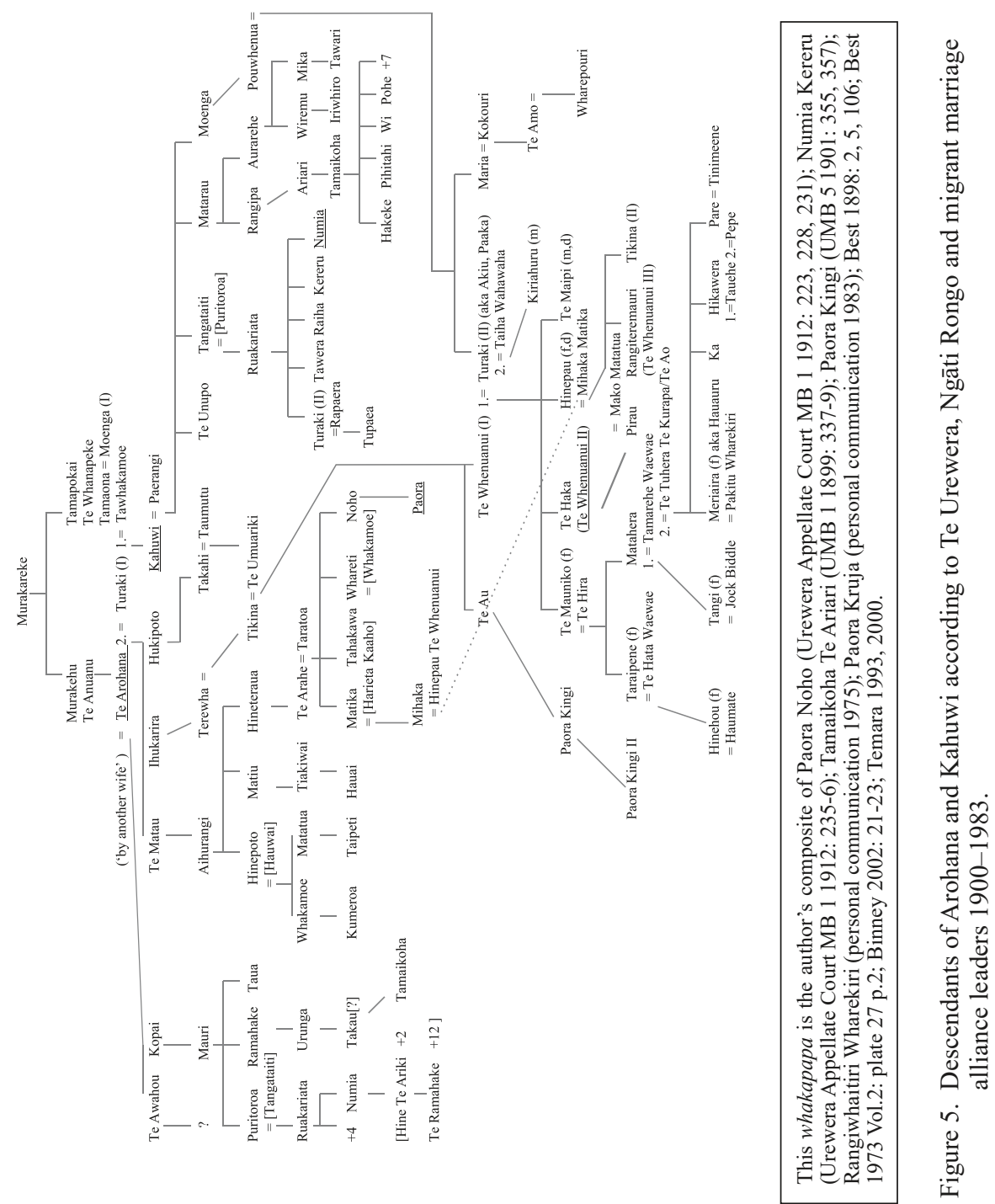
The structural difference between whänau 'extended family' and hap $\bar{u}$ was emphasised in discussion of the Commission's difficulties in defining blocks by hapu. Wolf's careful distinction between kinship in terms of filiation and marriage, and kinship in terms of consanguinity and affinity (criteria 1-3), is exemplified in the distinction between whānau and hapu $\bar{u}$. The "extension" of the former familial or domestic level of kinship to the latter "transgenerational" level was typically assumed to occur in the development of hunters and gatherers into agricultural societies. But Wolf emphasises instead that this extension beyond simple parent-child and marriage bonds "is concerned with jural allocation of rights and claims, and hence with political relations between people", and that marriage in the anthropological sense of "affiliation" "becomes a tie of political alliance between groups".

Like most Māori at this time, among Tūhoe the "social clusters" that lived and worked together accumulating "a transgenerational corpus of claims and counterclaims to social labor" (criterion 1) were actually whānau, domestic groups or extended families rather than descent groups. While members of a hap $\bar{u}$ lived dispersed across different localities reflecting their rights by common ancestry and intermarriage (that is, by consanguinity and affinity), whānau affiliated with that hapu were the groups that actually occupied and cultivated, herded, hunted or gathered on the land. Nevertheless, the transgenerational claims and counterclaims to the social labour of occupation or use of the land that whannau worked constituted the basis of their hapü's right to this land. The strength of this right relative to claims by other hapu was what was tested and decided before the UDNR Commission.

However, as the block lists showed, the hapu descent groups recognised to have maintained these ancestral rights through occupation or use at least since a great-grandparent's generation did not include among them spouses or other members of the whannau who were not considered members of the same descent group. If these whānau members could also claim descent from the same or another ancestor recognised to hold the hapu rights to that block, they might appear in the same block list, but along with their own siblings and descent group rather than that of the whanau with whom they lived and worked. In the case of spouses, insofar as these two descent groups could usually be no more closely related than fourth cousins, the different ranking of relative rights recognised in the block made it likely that their descent group would be located and ranked quite differently in the block list.

As well as the fact that it is whänau not hapu that live and work together in a locality, the popular and official misconception that Māori whānau were simply the bottom tier of a hierarchical organisation of $i w i, h a p \bar{u}$ and whannau (that is, that hapu are composed of whänau) leads to confusion between them. Whānau necessarily straddle different descent groups due to the incest taboo, 
and often straddle different hapu. Significantly reflecting this confusion between whānau as extended families and hapu as descent groups, the legal order drawn up by the UDNR Commission chairman to accompany the 1903 block lists misleadingly identified sibling groups bearing the same surname as "family groups" or "ropu whanau" in the accompanying translation). This was further confused because neither parent was included in these "whanau" and the father bore a different "surname" (following Native Land Court practice, the European convention of patronymic surnames was imposed by the Commission, requiring that as well as their "first" name, all claimants be additionally identified by their father's first name; only later did this personal name come to be generally accepted by Tūhoe as a family "surname"). I argue that the conflation of whānau with descent groups is central to Jeff Sissons' case that Māori hapū are organised like medieval European "houses" rather than cognatic descent groups and categories (Sissons 2010; Webster 2011, 2013).

The organisation of whânau was probably inherently ambivalent (as it often still is) insofar as in its social labour a whānau tends to extend its filial/ marriage roles across the consanquineal/affinal roles of hap $\bar{u}$ to which it was affiliated. The key role of its social labour might over-ride formal requirements of common ancestry. Ethnographic accounts of Māori kinship in the 1960s assumed hapu were defunct partly because "bilateral descent" or taha rua 'two-sided' filiation originating from the perspective of whannau tended to recognise kin as an ego-centred kindred rather than an ancestor-centred descent group. In 1975 I argued that this bilateral structure is normal to the straddle of a whānau between two or more hapū or iwi (1975: 148-49, 144, 130), and that hap $\bar{u}$ were not defunct at all. As whänau become more extended through their social labour in support of hapu, this affiliation through parents on both sides tends to become more selective among potential hapu affiliations, and a more exclusive ancestor focus of one or a few hapu come to over-ride the bilateral perspective of a two- or three-generation whānau. Among Tūhoe I have seen spouses and other members not closely related to the local hap $\bar{u}$ having to split their holiday visits to two different parts of the country and, when at the Tūhoe hapū homestead, they were excluded (as was I and my family) from hap $\bar{u}$ meetings about lands and other internal hapu issues.

On the other hand, the strong Māori ethic of inclusion even of strangers demands that such whannau members be included at least peripherally in hap $\bar{u}$ activities, and residence along with commitment in social labour for the hapu increasingly establishes practical if not formal membership. In the case of a resident spouse married in from another hapu, the children of a mature marriage (full members, of course) as well as other forms of "accumulated" social labour (criterion 1) ensure such honorary membership and nominal rights of their non-member parent. Occasionally the accepted leader or 
kaumātua 'elder' of a whānau and even the rangatira 'chief' of a hapu will be a spouse who has married in from another hapu (almost always a husband). In formal genealogical debate such rights are distinguished (or stigmatised) as relying on whakapapa whakamoe "claiming inclusion in a descent group by marriage into it' (Webster 1975: 140-41). As will be described later, in the 1912 subdivision of the Manawaru area of Ruatāhuna block the Ngāti Rongo hap $\bar{u}$ leader Numia Kereru successfully_but misleadingly — challenged on this basis land rights claimed by Te Urewera hap $\bar{u}$ and migrant marriage alliance leaders. Ironically, the same stigma was sometimes raised against his own ancestor Rongokarae, the founding ancestor of Ngāti Rongo hapu (and after whom their Ruatoki meeting house is named), because he had married two Ngāti Rongo sisters but himself had immigrated from another $i w i$ entirely.

As described in the introduction above, the second part of my study of the UDNR pursued the implications of the aborted 1902 proposal to amalgamate the 34 blocks of the reserve into just ten titles (Fig. 3). In terms of Wolf's thesis regarding kinship and power, this proposal was probably supported or may even have been proposed by influential Tūhoe rangatira (including the Tühoe commissioners) seeking to extend their control over the mobilisation of social labour beyond hapu in nominal control of each block. Since 1899 the Commission had struggled with increasing numbers of claims and counter-claims of subordinate hap $\bar{u}$ aspiring to independence from other $h a p \bar{u}$, and these resulted in mounting appeals that would have to be settled by an unpredictable Appeals commission with no Tūhoe representation before the reserve could finally be formally established. By 1902 the advantages of subsuming these impending confrontations by amalgamating groups of blocks under more centralised leadership of fewer and more dominant rangatira would have appealed to the Pākehā as well as the Tūhoe commissioners.

This strategy probably took advantage of established "clusters" of hap $\bar{u}$ that could control each amalgamation through the dominance of one or two hapu $\bar{u}$ in each cluster (Ballara 1995; see also see Ballara 1998: 279-301). In the four cases that were examined closely (Fig. 3: Te Whaiti Nui a Toi, Ohaua te Rangi, Parekohe, and Ruatāhuna-Waikaremoana) it became clear that hap $\bar{u}$ clusters straddling the proposed amalgamations were controlled by a few dominant sibling groups or their descendants who, furthermore, usually had established rights in adjacent blocks. As outlined earlier, in two of these cases an extensive marriage alliance between several descent groups was discovered which included these leading sibling groups. The extent and duration of these marriage alliances suggest that over several generations their leaders had been able to extend their power through mobilisation of the social labour of their widening descent groups, weakening the claims of some established hapu, while strengthening others. 
Regarding the proposed Ruatāhuna-Waikaremoana amalgamation, in the second part of Volume I (Webster n.d.b) I argued that the marriage alliance (Fig. 4) had been developed among migrants between the two blocks since the early 1800s "conquest" of Waikaremoana lands by Tūhoe and allied Ngāti Ruapani hapu who occupied Waikaremoana but had been under the control of another iwi, Ngāti Kahungunu to the south. What the Tūhoe saw as a "conquest" was probably a prolonged assimilation through intermarriage with some friendly Ngāti Ruapani hap $\bar{u}$ and gradual annexation of some Ngāti Kahungunu land under their control. In terms of Wolf's thesis, several generations of migrants moving between the "conquered" Waikaremoana and adjacent Ruatāhuna and Maungapohatu areas had been prevented from gaining wider Urewera rights due to stigma as migrants lacking long-term occupation. Nevertheless, through rising leaders who could mobilise the migrant marriage alliance's social labour, they had gained increasing control over Ruatāhuna as well as Waikaremoana, probably best explaining the 1902 proposal to amalgamate the two blocks.

Most importantly, by late 19th century the Ruatāhuna-Waikaremoana migrant marriage alliance had been extended to the renowned war leader Te Whenuanui Te Umuariki (Te Whenuanui I), the rangatira of Te Urewera hap $\bar{u}$ with mana throughout the Ruatāhuna area, by way of marriages of two of his children (Figs 4 and 5). In the next section below, the series of confrontations involving leaders of this alliance, Te Whenuanui II, Numia Kereru Te Ruakariata, Tutakangahau Tapui, and the several hapu they led, will be reviewed in terms of Wolf's thesis of kinship and power, especially criteria $6-8$ above.

However, before returning to this issue, what can be said of the "mythological charters ... of kin connection" underlying and reinforcing Tūhoe leaders' mobilisation of social labour (criterion 5)? The recognition of founding ancestors for each block was often contested but nevertheless treated almost mythically. Although founders were usually more recent, Best's Tūhoe genealogies record whakapapa presented in evidence to extend through more than 30 generations (Best 1973 [1925], Vol. II). Strikingly suggesting "transgenerational" bodily identity, claimants would often refer to predecessors, even recent ones and sometimes claimants themselves, as if they personified the hapu itself or its founder him- (or her-) self. The mana of certain ancestors was often mythologised, merging with the demigod status of primal ancestors who had immigrated to New Zealand from legendary distant islands. As Binney's careful research revealed, the identification of Te Whenuanui II and III with Te Whenuanui (I) Te Umuariki was so immediate that they have been frequently confused even by contemporary Tūhoe authorities (Binney 2002: 22 fn 38; Fig. 5). Some old leaders from 
the 1860s Land Wars such as Tamaikoha and their successors such as Te Whenuanui II, were clearly deferred to by the Commission, and quietly allowed to circumvent the usual investigative procedures for some land claims that were apparently so highly respected that they went unchallenged. It turned out that Numia Kereru, as successor to his elder brother Kereru Te Pukenui, also exercised his growing influence behind the scenes but, perhaps because he was himself a commissioner, this was carefully kept out of the Commission's records.

Similarly, the Urewera landscape was mythically animated. Boundaries of the land areas were symbolically staked out and contested in terms of place names of mountains, hills, streams, trees, rocks or events said to have been bestowed by ancestral founders or explorers, and substantiated with oral traditions regarding these names, as well as the persons who bestowed them. Like the acts of ancestral demigods, the mana or power to bestow a place name sanctified it and its place (although this was sometimes contested between hap $\bar{u}$ ). Accompanied by knowledgeable elders, the surveyors often had to deal with such "mythological charters" and noted them on sketch plans that were put before the deliberations of the Commission. As in Native Land Court investigations of original title, witnesses' ability to recite the iconic details of these traditions carried weight as evidence for claims.

The basic concepts underlying evidence presented for a claim to original title had long been established in the Native Land Court (Webster 1975: 133-35). Guided by one or more commissioners who were also judges of the Court, as well as Tūhoe commissioners experienced in that court, the UDNR Commission followed principles probably already widely customary among Māori: land rights transferred by conquest, gifting or aroha 'compassion', as well as ancestry; all these take 'reasons' requiring occupation within the last three generations as well as descent from a founding ancestor (discriminated as ahi kā, ahi teretere or ahi mätaotao; 'burning', 'flickering' or 'cold hearthfires', respectively); and a distinction between rights to specific resources of the land and rights to the land itself. However, in accord with the home-rule intentions of the 1896 Act, as described above, the UDNR block owner lists went much further in deference to the Tūhoe leaders' informal negotiation of elaborate ranking of relative rights of descent groups between as well as within most of the 34 blocks of the reserve.

Although the Commission's hearings themselves were apparently not ceremonialised, there is little doubt that their reception and hosting at each sitting was carried out with elaborate marae kawa 'ceremonial protocol' and symbolism similar to what has often been described for contemporary Māori hapu (Salmond 1976; Webster 1975: 129-33). Generous hospitality would have been competitive between hapu controlling the various host marae. In 
addition to the commissioners and their retinue, records and equipment, the host would be expected to feed and probably house many Tūhoe claimants and observers who had come from other parts of the Urewera for the scheduled cases. The heightened confrontation between hap $\bar{u}$ vying for independence, as well as counter-claimants, probably added considerable drama to these ceremonies, but would usually be carefully muted in the Commission's records. In any case, hosting the Commission was a burden upon hapu resources and clearly a display by their leaders of their power to mobilise social labour as well as marshal the needed food and materials derived from previous social labour.

\section{DID TŪHOE BREAK THROUGH THE BOUNDS OF THE KINSHIP ORDER?}

As summarised above in criteria 6-8, Wolf saw such competition or confrontation for influence or power over social labour as "one of the Achilles' heels of the kinship mode" (criterion 6). Given the immediate context of the Crown's patronage in the form of the UDNR Commission, as well as the wider emergence of hap $\bar{u}$ compromises with capitalism by the $1890 \mathrm{~s}$, did such displays of kin-ordered power threaten to break through the bounds of Tūhoe kinship?

This question can be approached through a closer review of the series of confrontations between Ngāti Rongo and Te Urewera hapu already mentioned. As detailed in the last part of Volume I, this situation emerged between 1899 and 1912 in a four-way confrontation (eventually revealed to be two-way) over rights in Ruatāhuna and Waikaremoana lands between the migrant marriage alliance, Te Whenuanui II as a leader of Te Urewera hapu and the migrant marriage alliance, Tutakangahau as leader of Tamakaimoana $h a p \bar{u}$, and Numia Kereru as leader of Ngāti Rongo hapū. The shifting but strikingly persistent confrontation between the migrant marriage alliance and Tamakaimoana hapū and their leader Tutakangahau over the northern part of Waikaremoana erupted before the Investigative Commission and then again the Appeals Commission 1901-1907 (see Fig. 2 where this northern part is marked out). Although it was not apparent at first, by 1903 it was clear that Numia Kereru and Te Whenuanui II were also implicated behind the scenes of the confrontation over rights to Waikaremoana block.

Numia Kereru's persistent claims to the Manawaru part of Ruatāhuna block against the resistance of Te Whenuanui II and his supporters in the migrant marriage alliance appear to have been central to the wider confrontation (see Fig. 2, where the Manawaru part of Ruatāhuna is marked out as the Arohana and Kahuwi partitions established in 1912). Numia's initiatives emerged before the Investigative Commission 1901-2, again in the 1907 Appeals Commission hearings, and still later in the 1912 partition of Ruatāhuna. His strategy revealed what is probably best understood as the advantage of a leader 
confident in deploying the power of government patronage and his role in an official commission, along with his own rising mana, to wear down the more traditionally-based power of Te Haka Te Whenuanui II, successor to an old warleader of great mana. Although Numia's final gain in Ruatāhuna land and resources for Ngāti Rongo hapu may seem small, his and this hap $\bar{u}$ 's gain in mana or influence was probably considerable, and that of Te Whenuanui II and even the Te Urewera hap $\bar{u}$ was weakened, at least for a time.

Numia Kereru Te Ruakariata was influential in Prime Minister Seddon's dramatic tour through the Urewera in 1894 and became central as the following negotiations in Wellington developed. Seddon's tour was hosted on Tauarau Marae in Ruatoki by Numia's elder brother Kereru Te Pukenui and escorted subsequently to gatherings in several Urewera settlements and finally across Lake Waikaremoana by Kereru's first-born sister's son Tupaea Rapaera (Fig. 5), who is said to have rescued the Prime Minister there from an overturned canoe (Webster n.d.a). Tupaea's mana and extraordinarily extensive land rights throughout the Urewera probably also ensured the continuity of his uncle Kereru Te Pukenui's influence throughout the tour, Seddon's inspired support for Tūhoe home-rule and, along with Numia Kereru, the negotiations with Tūhoe leading to the 1896 UDNR Act. The taiaha 'wooden spear' named Rongokarae, gifted in 1894 by Kereru to Seddon in Ruatoki and recently returned by the Government in honour of the 2014 Te Urewera Act, bore the name of the Tauarau Marae's meeting house, as well as the ancestral founder of Ngāti Rongo hapu, and may have been the one used ceremonially by Tupaea Rapaera.

Soon after Seddon's tour Kereru Te Pukenui died, and Numia's (and Tupaea's) influence became central in the Wellington negotiations. Soon Numia took on his brother's name (hence "Numia Kereru") as a sign of his continuing leadership. He was also prominent in Native Land Court and Appellate Court cases of the 1890s, sometimes in confrontation with other Tūhoe leaders (such as Tamaikoha in the Whaitiripapa claim). A story still told among Tūhoe might have forecast his rising influence and even readiness to break through the bounds of the kinship order. In the 1890s Numia was widely criticised for having the Ruatoki block surveyed against the resolutions of the leading rangatira (including his brother Kereru) to allow no surveys anywhere in the Urewera. Numia furthermore confronted Ruatoki rebels who had pulled up surveyors' stakes and turned several rebel women over to the local Pākehā authorities, resulting in their imprisonment in Auckland until the survey was completed. Numia's actions were widely seen at the time as a betrayal of Tūhoe solidarity, although his actions were later supported in a visit to Ruatoki by the prestigious prophet Te Kooti Rikirangi. In the subsequent meeting with Prime Minister Seddon in 1894 Numia also adroitly defended Tūhoe interests. 
By 1899 Numia Kereru (as well as Tutakangahau) had been selected by Tūhoe as one of their five UDNR commissioners. By the end of the following year the chairman urgently pressed for more expedient procedures by combining minor with major claims. Numia was the lone objector, warning that such a subordination of legitimate claims would lead to needless conflicts. Although such "minor" interests as that which he had gained for Ngāti Rongo in Whaitiripapa block against Te Urewera hap $\bar{u}$ - and would soon attempt to gain in Ruatāhuna-may have been a motive, his lone stand probably indicated a defence rather than a break from the kinship order of minor or subordinate hap $\bar{u}$ aspiring to independence. His election to membership in several hapu or block committees by 1902 reflected his rising mana among other Tūhoe leaders as well as the extensive land rights held by his descent group. After the reserve was finally established in 1907, Numia was furthermore elected chairman of the UDNR General Committee by other Tūhoe leaders, after having successfully insisted that followers of Rua Kenana the prophet (who was attempting to sell extensive Urewera lands to the Government) be banned from the Committee. As chairman of that committee he had statutory power over any alienations of Urewera land, and throughout 1908 he successfully evaded the Government's mounting pressure to sell by offering only short-term leases. Finally, Apirana Ngata, acting for the Government, forced inclusion of Rua Kenana's followers on the General Committee and Rua's extensive sales began (Webster n.d.a). This was the onset of the Crown's systematic betrayal of the 1896 Act.

Eight years later in 1916 Numia died, certainly in mounting frustration to defend the deviously circumvented home-rule of an inalienable reserve he had helped to establish for Tūhoe. By that time he was confronting the predatory acceleration of the Crown's illegitimate campaign to bypass his General Committee and purchase from individual Tūhoe (Webster 2004: 143-213). His impressive career at least displayed the potential power of Māori kinship in the face of Crown power.

However, it might also be concluded that in other ways Numia's rise to power broke through the bounds of the kinship order. His sometimes ruthless manner in pressing his claims against Tūhoe adversaries in Court as well as before the Commission, and through his sophisticated courtroom skills gaining the support as well as admiration of Court and Commission officers, might be seen as weakening or even transgressing the Tūhoe kinship order. Although he, along with other Tūhoe commissioners, were supposedly stood down in cases where they had claims to be heard, his influence behind the scenes was probably pervasive and sometimes even subversive of other Tūhoe claimants. Beginning with his elder brother's reception of Prime Minister Seddon in 1894, he and his Ngāti Rongo hapū at Tauarau Marae in Ruatoki 
were usually the hosts of Commission sittings in that part of the Urewera. Their quiet presence and generous hospitality could not have been overlooked.

It turns out that crucial hearings of the long-running cases of both Ruatāhuna and Waikaremoana were often heard in close succession at Tauarau Marae, although Numia's role as presiding host remained muted in the records. Meanwhile, his and Ngāti Rongo's open campaign against Te Whenuanui II and Te Urewera hap $\bar{u}$ in the Ruatāhuna case contrasted dramatically with his relatively hidden role in the Waikaremoana case, where it turned out his support of Tutakangahau's persistent attack on the migrant marriage alliance's control of northern Waikaremoana was crucial. Numia had drawn up Tutakangahau's claimant list for Tamakaimoana hapu and even submitted it through a leader of the migrant marriage alliance (Te Wao Ihimaera; see Fig. 4), but Tutakangahau's case lost the 1901 decision, probably for lack of Numia's presence and advice. There is some evidence that Numia absented himself in retaliation for Tutakangahau's son's defeat of his claim to a small part of Maungapohatu block.

Nevertheless, by the end of the following year Tutakangahau's whannau and most of Numia's list of Tamakaimoana claimants had been included in the Waikaremoana block order despite the dismissal of their claim, probably due to Numia's intervention behind the scenes and the Commission's deference to him. The apparent disregard of this decision may have been in compensation for the Commission's earlier decision to include the northern portion of Waikaremoana in Maungapohatu (see Fig. 2), probably to satisfy Tutakangahau and Tamakaimoana demands and punish Te Wao's exclusion of Tamakaimoana claimants contrary to previous agreements. Although this earlier decision was ignored in the final boundaries (leaving the northern portion in Waikaremoana block), it was never formally rescinded.

Numia's overt role in the quite different Ruatāhuna case nevertheless had revealing similarities with his covert role in the Waikaremoana case. In 1902 his apparently respectful but insistently repeated request to $\mathrm{Te}$ Whenuanui II to accept Kahuwi along with Arohana as founding ancestors of Ruatāhuna (Fig. 5) was pre-emptorily settled by the Commission in what appeared to be naively presented by them as a compromise. However, instead of a compromise, the decision was certainly an insult to Te Whenuanui II's mana over the Ruatāhuna block, insofar as it granted Kahuwi equal rights with Arohana over the whole block, as well as its Manawaru part. Probably alerting Te Whenuanui II to the threat behind Numia's requests, Kahuwi was the same ancestor through whom Numia had won Tamaikoha's compromise of Te Urewera hap $\bar{u}$ 's rights in the Whaitiripapa case in 1900, reviewed above. Numia was not even required by the Commission to meet Te Whenuanui II's argument that Kahuwi was adopted by Arohana and therefore had no rights 
in Manawaru at all other than those given in aroha 'compassion' (see Fig. 5: Kahuwi's birth-father Tawhakamoe had died in battle and was found kahu wi 'dressed (covered) in reeds'). A decade later, after Te Whenuanui II's death, this oversight was to give Numia the decisive advantage in his strategy to claim part of Manawaru.

Between the likelihood of Numia's influence behind the scenes in the admission of Tutakangahau's claim to the Waikaremoana title despite dismissal of the latter's case, and Numia's successful public challenge to the mana of Te Whenuanui II in Ruatāhuna, by the end of 1902 the leaders of the migrant marriage alliance and Te Whenuanui II had found common cause in the defence of both Ruatāhuna and Waikaremoana lands against Numia's incursions. Several appeals by or in support of Te Whenuanui II in 1903 were signed by members of all five of the original descent groups of the migrant marriage alliance (Fig. 4). This dramatic closing of ranks against Numia's incursions in both blocks can be seen as Te Whenuanui's and his supporters' mobilisation of control over the social labour of Te Urewera hap $\bar{u}$ and the migrant marriage alliance, as well as their extensive land resources, which would have been reinforced by the amalgamation of Ruatahuna and Waikaremoana.

Nevertheless, Numia Kereru's personal influence, power, or mana was not to be stopped. As well as by 1907 gaining significant if largely symbolic rights in Waikaremoana for Tutakangahau's whannau and many others of Tamakaimoana $h a p \bar{u}$, by 1912 Numia had forced his (or rather, the ancestor Kahuwi and Ngāti Rongo hapū's) way into Manawaru and a prized area of Ruatāhuna block. Te Whenuanui II's unexpected death by the time of the 1907 appeals hearings probably finally opened the way for Numia and Ngāti Rongo's triumph against him and the migrant marriage alliance in Ruatāhuna as well as Waikaremoana.

Although the several 1903 appeals reflected the mobilisation of the migrant marriage alliance and Te Whenuanui II against Numia's initiatives in both blocks, even that early they had carefully avoided reference to the adverse or ambiguous decisions as well as Numia's role in them. This restraint was probably in fear that his courtroom skills would set the Appeals Commission further against them. However, when the Appeals Commission was finally convened, the 1907 hearings on Waikaremoana and Ruatāhuna were strangely muted, with none of the key issues in either block being raised by either the appeals commissioners or the appellants, defenders or participants. Although the dismissal of Tamakaimoana hapü's claim to Waikaremoana was raised by the spokesperson for the migrant marriage alliance (Mahaki Tapiki, Fig. 4), the ambiguous status in which its northern portion had been left was overlooked even by the commissioners. Compounding this ambiguity, they 
appeared to ignore the appeal against the inclusion of dismissed claimants, instead insistently asking who had drawn up the list in the first place. When it was finally revealed that it was Numia who had written out the dismissed list, the Appeals Commission simply concluded that they could not believe there had been any mistake in including it in the Waikaremoana title, ignoring its dismissal by the Investigative Commission.

The appeals commission's decision with regard to the unexplained changes of shares in Ruatāhuna appealed against by Te Whenuanui II and the migrant marriage alliance was even more pre-emptory. The key issue of Numia's demand that Te Whenuanui II recognise Kahuwi as well as Arohana as founding ancestors of the block was never raised by either the Commission or the appellants, let alone the questionable grounds of the previous Commission's decision that share allocation should treat them equally while neglecting to require Numia to answer Te Whenuanui II's defence that Kahuwi was adopted by Arohana and therefore had no rights at all beyond token shares in aroha. Instead, when Numia finally admitted that he himself had reduced the final share allocations and offered to resolve the appeals outside of the hearing, the settlement was simply turned over to him and results approved with no questions asked.

The apparent conspiracy of silence between the Appeals Commission, appellants and participants in these cases, and the Commission's casual deference to Numia Kereru's interventions in both cases, are best explained by their concurrence soon after the sudden death of Te Whenuanui II on 2 January 1907 from being thrown and dragged by a horse (Temara 1993, 2000). Binney's discovery of correspondence clarified the frequent contemporary confusion between Te Whenuanui I (Te Whenuanui Te Umuariki) and II (Te Haka Te Whenuanui) and, furthermore, succession to Te Haka's title by a Te Whenuanui III (Rangiteremauri Mahaki) (Fig. 5; Binney 2002: 21-23). Benefitting from Binney's ground-breaking evidence, I was able to argue that it also suggested Numia took advantage of Te Whenuanui II's sudden death to elaborate his strategy for gaining Ngāti Rongo rights in Ruatāhuna.

Perhaps during the hearing of both Waikaremoana and Ruatāhuna appeals 1-5 February 1907, Numia had arranged wide Tūhoe agreement that Te Whenuanui II's sister Hinepau's son Rangiteremauri would succeed as Te Whenuanui III regardless of other perhaps more appropriate successors (Fig. 5). A few months later, on 27 April 1907, Numia announced this arrangement in a letter to the Native Minister "Timi" (James) Carroll, reassuring him in candidly personal terms that he Numia could act as Te Whenuanui's III “counsellor". Insofar as leaders in Ruatāhuna were known by the Government to be among the most troublesome of Tūhoe hap $\bar{u}$, the Native Minister as well as Numia would have known this arrangement might be to 
their mutual advantage, putting Numia "in a position to forward or to hinder their interests" (criterion 8). Furthermore, I learned from a contemporary descendant of Numia's that he had gained Ngāti Rongo rights in Ruatāhuna through an agreement with Ngāi Te Riu, one of the several hapu recognised by the Commission to have established rights there (primarily in Waiiti and Huiarau areas, immediately south of Manawaru).

This information clarified Numia's probable motives in his 27 April letter to the Native Minister for tracing the new Te Whenuanui III's descent from his father's mother's brothers Ahikaiata and Tupara Kaaho. Strikingly, in doing this Numia ignored Rangiteremauri's descent — and actual right to the titlefrom his mother Hinepau's (and her brother Te Haka's) father Te Whenuanui (I) Te Umuariki (Fig. 5). While the Kaahos were leaders of Ngāi Te Riu hapu, by not mentioning Hinepau's husband Mihaka Matika and Mihaka's father Matika Taratoa (see Fig. 4), Numia was also probably avoiding implication of major leaders in the migrant marriage alliance. Although having lost the protective mana of Te Whenuanui II, the alliance was the surviving source of resistance to Government's rising interest in Waikaremoana as well as Numia's plans for Ruatāhuna. While Matika Taratoa's wife and Mihaka's mother Hariata Kaaho, sister of the leaders Ahikaiata and Tupara, could give Numia influence in Ngai te Riu hapu, Matika himself was the mātāmua of the Taratoa sibling group whose mother was Te Arahe, the great-great-granddaughter of the founding ancestor Arohana (see dotted line in Fig. 5). Whether or not the Native Minister appreciated it, as counsellor to Te Whenuanui III Numia had placed himself at the intersection of both a source of Te Urewera hapu's mana in Ruatāhuna and key leadership in the migrant marriage alliance, as well as Ngai Te Riu hapu leadership.

The confluence 1-5 February 1907 of both the well-attended Waikaremoana and Ruatāhuna cases (although in Whakatane rather than at Tauarau Marae), Te Whenuanui II's death, and Numia's opportunity to negotiate increased shares for leaders of the migrant marriage alliance in Ruatāhuna was probably the turning point in Numia's strategy. By the time of the Ruatāhuna partition in 1912, the loyalty of most of the leaders of the migrant marriage alliance in support of Te Whenuanui II's refusal to admit Kahuwi and Ngāti Rongo rights in Ruatāhuna had been quieted. The extensive case was heard before the Native Appellate Court and conducted entirely by Numia Kereru. His (and Ngāti Rongo hapü's) new influence at the intersection of Ngai Te Riu $h a p \bar{u}$, Te Urewera hapu, and the migrant marriage alliance, as well as Te Whenuanui II's death, probably accounts for his success in finally gaining the Kahuwi partition of Manawaru for Ngāti Rongo, as well as facilitating his role in the whole partition case. At the conclusion of several weeks of hearings, the Chief Judge, obviously impressed by Numia's skills inside as well as outside the Court, publically complimented him for his efforts. 
It was probably not coincidental that the Taratoa sibling group (and thus Mihaka Matika and his son Te Whenuanui III; Fig. 5) were the major beneficiaries of Numia's increase of Ruatāhuna shares in 1907. Perhaps also because of the dominant mana of the Taratoa cousins (Mihaka Matika, Whenua Tahakawa and Paora Noho) among the other four descent groups of the migrant marriage alliance, they were left with the responsibility of defending Te Whenuanui II's refusal to accept Kahuwi's descendants' rights in Ruatāhuna against Numia's demand. Nevertheless, Numia's tactics against their case were ruthless.

Numia's appeal to partition Ruatāhuna block was made in terms of hap $\bar{u}$ boundaries and relative interests by which Ruatāhuna could be partitioned into five divisions, but his own personal interest in the Manawaru division was played down by treating it as an internal boundary dispute. In the event, Numia was soon able to announce settlement of all other boundaries excepting this boundary dispute internal to Manawaru. The Chief Judge apparently heard nothing of the history of the confrontation and little about Ngāti Rongo, Te Urewera $h a p \bar{u}$, and Te Whenuanui II's previously central role in opposing Numia. This history, probably silenced by Numia's control of the proceedings, was represented only by the case to be made by the Taratoa cousins.

Numia's offensive strategy led with his complaint that the "others" (that is, the Taratoa cousins) had been tardy in their preliminary meeting with him, and announced that the boundary between the disputed portion of Manawaru and the adjacent Waiiti part of Ruatāhuna had been agreed between himself and the Waiiti leader (Fig. 2; Manawaru is comprised of subdivisions Kahuwi and Arohana). The Taratoa cousins would have been aware that this agreement, if accepted by the Court, would pre-empt their intention to claim the whole boundary between Manawaru and Waiiti. They would furthermore have been aware that the leader for Waiiti was Te Iriwhiro, Numia's ally in their 1902 demand to Te Whenuanui II that ended in the Commission's compromise decision to recognise rights for descendants of Kahuwi equal to those of Arohana. The Waiiti division was recognised to be controlled by Ngāi Te Riu and Ngāti Kuri hapu, so the pre-emptory agreement between Numia and Te Iriwhiro may have been part of Numia's arrangement with Ngāi Te Riu to back his demand that Kahuwi be recognised as a founding ancestor in Manawaru. Te Iriwhiro was among the leading descendants of Kahuwi (Fig. 5, to right of Numia).

Either discouraged by such indications of Numia's aggressive strategy or refusing to expose his mana to further insults, the senior Taratoa representative Mihaka Matika did not speak again, apparently turning the rest of their case over to his junior cousins Whenua Tahakawa and Paora Noho. Again, Mihaka was the son of Hariata Kaaho, husband of Hinepau, brother-in-law of Te Whenuanui II, and father of Te Whenuanui III, so his leading role 
in the Taratoa cousins' case may have already been compromised in all these ways by Numia's strategy. On the other hand, there is evidence that Whenua Tahakawa may have been considered in 1900 to lead the case for Te Whenuanui II and Te Urewera hapū in their defence against Numia and Ngāti Rongo's claim for Whaitiripapa block, which had finally been successful on the grounds of Kahuwi's founding ancestry there.

Although Paora Noho confidently laid out the alternative whakapapa that supported the ancestor Arohana's but not his adopted son Kahuwi's rights to Manawaru (Fig. 5, left side), his own case and responses to Numia's questions were apparently weak and increasingly defensive - so far as can be assessed from the Chief Judge's casually fragmentary minutes. Numia's case rested primarily on an argument that although Kahuwi was adopted by Arohana and therefore had no birthrights to Manawaru, Arohana had gifted a large part of the area to Kahuwi and this had been accepted among Arohana's birth-children (Kahuwi's adoptive siblings). In 1902 when Te Whenuanui II had finally sprung the adoption as his defence, Numia had not attempted to rebut it — nor had the Commission required him to. However, by 1912, with Te Whenuanui II dead and his supporters in disarray or compromised, Numia clearly had a rebuttal well-planned.

An unexplained but important issue must be raised here regarding the implication that Kahuwi's rights in Manawaru were limited insofar as he was only a tamariki whängai 'adopted child' or step-son of Arohana. Although I have made it clear in Figure 5 how Arohana was actually an "uncle" to Kahuwi (in Māori terms, being fourth or fifth cousins as descendants of Murakareke), for some reason Numia never raised this crucial fact. According to contemporary and probably traditional Māori custom (Milroy 2001), adopted children may be included in their adoptive siblings' birth-rights if they are close relations (usually within fourth cousins' range, as indeed they usually are in Māori adoption). One would suppose that this would have readily settled Numia's claim for Kahuwi's rights even in the 1902 confrontation with Te Whenuanui II as well as in 1912. Te Whenuanui II's reluctance to grant Kahuwi's descendants anything more than small shares in aroha suggests that he too was dismissing this custom. There must have been some compelling reason for Numia to have not raised it on either occasion.

Most demeaningly against his adversaries, Numia's carefully timed presentation of whakapapa segments charged that Te Whenuanui Te Umuariki's (Te Whenuanui I's) own right in the disputed portion of Manawaru - and even that Paora's own father's right — was owed to their wives' right from their ancestor Kahuwi rather than their own right from Arohana (as pointed out above, land rights enjoyed only through one's spouse may be relatively stigmatised as whakapapa whakamoe). Although 
when Numia put these accusations directly to Paora he denied them, Paora apparently did not take the opportunity to point out that the whakapapa he had presented (which Numia had not challenged) made it clear that Te Whenuanui I's father was Te Umuariki, and that his own father's mother was Te Arahe, and that both these predecessors were direct and close descendants of Arohana (Fig. 5). Paora's apparent neglect to firmly rebut Numia's bold insinuations was a major oversight, and remains inexplicable unless the minutes omitted such crucial evidence - or unless Paora had not intended to mount a strong defence against Numia's case.

Paora could also have countered Numia's tactics by pointing out that in 1902 Te Iriwhiro (Numia's ally then, as he was now in co-opting the boundary issue between Manawaru and Waiiti) had himself accepted Te Whenuanui II's claim that he had a "dual right" to Manawaru from both Arohana and Kahuwi. Numia made several other questionable claims, but most were apparently left unchallenged by either Paora or Whenua. Among other opportunities to humble Numia, his own (repeated) claim to such a dual right was apparently never challenged and left unsubstantiated. Given the recency of the ancestors Arohana and Kahuwi, subsequent intermarriage between Arohana's descendants by Kahuwi's mother Turaki I and Kahuwi's descendants would have been sufficiently rare to insist on substantiation of any claim to such a dual right, although the facts might be sensitive. As shown in Figure 5, Puritoroa was probably the wife of Numia's grandfather Tangataiti, and may have been the source of Numia's dual right; insofar as she was descended from "another wife" of Arohana's (Paora's evidence Fig. 5), this marriage may not have been sensitive to an incest restriction.

Finally, Whenua Tahakawa's concluding cross-examination of Numia appeared weak or hesitant, instead giving Numia further opportunity to emphasise the most favourable points of his own case. Even more so than Paora, Whenua apparently left Numia's reiterations of his own case unchallenged. Although the minutes taken of this exchange were too fragmentary to be certain, it is likely this reflected a foregone conclusion by the Court.

The decision of the Chief Judge was a triumph for Numia's strategy as well as for Ngāti Rongo hapū against Te Urewera hapū: settling two issues with one decision, the Court first accepted the boundary arranged by Numia and his old ally Te Iriwhiro between the disputed portion of Manawaru and Waiiti partitions of Ruatāhuna, and then declared that the weight of evidence was in favour of the boundary given by Kereru between the northwestern and southeastern subdivisions of Manawaru, thereafter called Arohana and Kahuwi (or Kahui). Te Whenuanui II's and the migrant marriage alliance's long effort to stem Numia's patient determination had finally failed. A case 
can also be made that their resistance had long been compromised, either by Numia's rising mana or by his subversive strategy, weakening opposition from the other four surviving decent groups of the alliance and, finally, even the Taratoa cousins supposedly in support of Te Whenuanui III.

$$
* * *
$$

In view of Numia Kereru's tactics between 1900 and 1912, as reviewed above, had his rise to power reached "a limit that can only be surpassed by breaking through the bounds of the kinship order" (criterion 6)? One could conclude such adroit use of the resources of capitalism (in this case, Crown support of Tūhoe's claim to the Urewera, and the Commission's support Numia's skills or mana) necessarily subverts the resources of kinship; or that such cynical use of kinship knowledge against itself undermines the whole kin-ordered mode of production. On the other hand, it could be argued that Numia's deployment of power was itself fundamentally kin-ordered; or that only some leaders but not their hapu had broken ranks; or that the kinship mode of mobilising social labour had only been selectively reinforced by the resources of capitalism. Perhaps the Taratoa cousins' apparent weakness was actually deference to the kin-ordered power of Numia's rising mana?

Tracing the details of the confrontation between Te Urewera hap $\bar{u}$ and Ngāti Rongo hapu between 1899 and 1912 led me to a clearer understanding of my own family's involvement with both hapū since 1972. In an effort to help us understand the array of distant kin we were meeting, our hosts (in Fig. 5, Pakitu Wharekiri's daughter or Paora Noho's son) sometimes sat us down and sketched out fragments of whakapapa in my notebook. Now it is clearer to me that we were being made familiar with a series of prominent marriages between about 1900 and the 1950s that we only dimly realised to be alliances between the two hap $\bar{u}$. These alliances had spanned the valleys of the Urewera just as they had spanned these hapu.

A double marriage between the two daughters of Te Mauniko Te Whenuanui (mātāmua daughter of Te Whenuanui I) and two sons of Waewae Te Roau (mātāmua Te Hata and his teina Tamarehe, Fig. 5) probably occurred around the turn of the century. This was around the time of the UDNR Commission's settlement in 1900 of the confrontation over Whaitiripapa block between Ngāti Rongo and Te Urewera hapu that had been in contention since the 1860s, and decided but then reversed before the Native Land Court in the 1890s. Now, finally, I have come to realise the fuller significance of this double marriage: because Te Roau and his mātāmua son Waewae (Te Kotahitanga) were the leaders of Ngâti Rongo at Ohaua, midway in the Urewera between Ruatāhuna and the other centre of Ngāti Rongo in Ruatoki, the two marriages of mātāmua descendants was seen to join Te Urewera hapū and Ngāti Rongo 
$h a p \bar{u}$ regardless of the Whaitiripapa confrontation. It may even have marked the settlement as a $p \bar{a} k \bar{u} h \bar{a}$ ' marriage gift' such as was said to have occurred in the 1860s. Furthermore, regardless of the bitter confrontations between these two hapu that continued over Ruatāhuna through 1912, several later marriages between their leading families continued at least through the 1950s. Perhaps these had even reached the point that now, as one Ngāti Rongo leader put it, Ngāti Rongo hapū was “just part of Te Urewera hapū”! Perhaps the two hapu have achieved what the Tūhoe call their tâtou pounamu 'our greenstone' peace-making.

Far from supporting Wolf's (1982) thesis of the vulnerability of power based on kinship, might this confrontation instead confirm Anne Parsonson's thesis that the Māori were a "competitive society" successfully using colonial venues in their traditional "pursuit of mana" (Parsonson 1980, 1981; see also Ballara 1982)? Following Ballara's 1982 critique I had long been dismissive of Parsonson's thesis. However, my belated appreciation of the power of Tūhoe marriage alliances and the ethnohistory reviewed above has given me pause in my scepticism. Nevertheless, although the 1894-1912 era can be seen as partly the traditional pursuit of mana between Tūhoe leaders, I must emphasise that this was inseparable from the specific context of a relatively benevolent administration, the 1896 UDNR Act, and a Crown Commission largely deferential to Tūhoe leaders in accordance with the spirit of that statute.

This integral role of Crown power in Tūhoe kin-based power was furthermore reversed within a few years, when Government policy toward the UDNR became systematically predatory, explicitly intended to weaken Tūhoe kinship organisation as well as taking most of their reserved lands. Indeed, the Crown tried hard to take all their lands and would have, had it not been for the surviving resistance of Tūhoe power based in their hapu or surviving descent groups (Webster 2004: 279-90). Although by 1907 Numia's form of leadership had won he mana motuhake 'an independent mana' for Tūhoe home-rule of their Te Urewera lands, already by 1908 he and his supporters were being marginalised. By 1912 when he triumphantly overcame the resistance of Te Whenuanui II and the migrant marriage alliance in Ruatāhuna and Waikaremoana, much of the UDNR, including those blocks was under grave threat from the same Crown that had worked with Tūhoe to establish it. Whether or not Numia had been breaching the bounds of the kinship order in his rise to power, by the time of his death in 1916, the power of Tūhoe kinship was being relentlessly suppressed or perverted beneath the power of the capitalist mode of mobilising social labour.

The over 200 mōrehu 'remnants' of their ancestral lands that through Tūhoe resistance had survived the Crown purchase campaign and Urewera Consolidation Scheme were relocated to make way for Crown pre-emptions 
or to be near promised roads, finally to lie scattered throughout what soon became the Urewera National Park. Although much of Ruatāhuna survived, virtually all of Waikaremoana was taken, both in bitter resistance (Webster 2004: 116-40, 554-96, 305-16; see also O'Malley 1996). Many of these small blocks remained occupied by their owners for a few more years, but by the 1930s their lack of economic viability, aggravated by the Government's failure to build the promised roads, forced most occupants out to surrounding towns for work and education of their children. Thereafter these blocks, scattered through the wilderness of the Park, continued to be visited by Tühoe crossing between the towns, hunting and gathering, remembering their dead buried in these places, and passing what memories of this chaotic history they could on to their children.

Since the 1950s various efforts have been made to bring the scattered remnants back to life, documented in Stokes, Milroy and Melbourne (1986) and later by voluminous research sponsored by the Waitangi Tribunal and the Crown Forestry Rental Trust to investigate the justice or injustices of that history. Again, the power of Government and the power of Tūhoe kinship, whether in cooperation or confrontation, remain inseparable. The resulting Tūhoe mobilisation suggests that the efforts of their ancestors, and perhaps especially those of Numia Kereru, Te Whenuanui II, their supporters and their opponents, had not broken through the bounds of their kinship order. Now, six generations after the Crown's betrayal and Numia's death, it remains to be seen if the seasoned power and solidarity of Tühoe kinship can regain the home-rule over Te Urewera that had been promised it in the 1896 UDNR Act and, perhaps, finally restored in the 2014 Te Urewera Act.

\section{NOTES}

1. Hap $\bar{u}$ are descent groups that trace their ancestry from a favoured ancestor cognatically, that is, through genealogical links of either gender. Hapu are often named after their favoured ancestor. A $h a p \bar{u}$ includes a wider category of members who trace their affiliation from the same ancestor, but whose active participation with the hapu $\bar{u}$ may be less strong, and whose primary affiliation may be with other hap $\bar{u}$ (Webster 1975).

2. The $i w i$ 'tribal' designation "Tūhoe" has probably always been controversial due to the sensitivity of associated hapu (so-called "sub-tribal") independence (Ballara 1998: 290-301). Currently and in the past, several large descent groups especially on the peripheries of the Urewera have insisted upon their recognition as independent $i w i$ while some Tūhoe may instead consider them to be hapu of the Tūhoe iwi. Thus my general references to "Tūhoe" must be taken to include other Urewera descent groups that may see themselves as independent $i w i$. This essay deals specifically with what I call the Ruatāhuna-Waikaremoana migrant marriage alliance that straddled several Tūhoe, Ngāti Ruapani and Ngāti 
Kahungunu descent groups and developed since the early 1800s. Tūhoe have traditionally considered this straddle to be a "conquest" rather than simply the result of intermarriage and political alliances. For this reason, I cautiously put the word in quotes. Members of this alliance usually affiliated with several Tūhoe hapū as well as Ngāti Ruapani, which has often considered itself a separate $i w i$, as does Ngāti Kahungunu further to the southeast.

3. These and other genealogies, and several specific cases, have convinced me that Tūhoe recognised an incest taboo or avoided (and continue to avoid) marriage between relatives closer than fourth cousins. Joan Metge (1967: 26) reported that "Within the hap $\bar{u}$, there were strong sanctions against marriage between first and second cousins". However, probably in 1929, citing his own East Coast $i$ wi Ngāti Porou, Apirana Ngata contested the common assumption of such a restriction, claiming that close-inbreeding, even marriage of first cousins was "extremely common" and "the rule rather than the exception" especially within "highly prized lines" of descent (Ngata n.d.). Bruce Biggs' study of traditional Māori marriage found some evidence that first-cousin marriages were disapproved (Firth 1962: 193). His finding that local descent group endogamy was encouraged to keep conflict limited to relatives may explain what Ngata identified as "close in-breeding".

\section{REFERENCES}

Ballara, Angela, 1982. The Pursuit of Mana? A re-evaluation of the process of land alienation by Māoris 1840-1890. The Journal of the Polynesian Society 91(4): 519-42.

1995. Porangahau; the formation of an eighteenth-century community in southern Hawke's Bay. New Zealand Journal of History 29(1): 3-18. 1998. Iwi: The Dynamics of Māori Tribal Organisation from c.1769 to c.1945. Wellington: Victoria University Press.

Best, Elsdon, 1898. Tuhoe genealogies 1898 (spine title); Genealogies of the Tuhoe tribe. Also includes all living members of the tribe in 1898, as given before the Urewera Commission set up under the act of 1896. Manuscript qMS [172]. Wellington: Alexander Turnbull Library. [NB: the author can supply an index for this resource.]

1973 [1925]. Tuhoe; Children of the Mist, Vol. I and II (genealogical plates), (2nd edition). Wellington: A.H. and A.W. Reed, Ltd.

Binney, Judith, 2002. Encircled Lands; Part Two: a History of the Urewera 18781912. An overview report on the Urewera. Report WAI A15. Waitangi Tribunal. Wellington.

Firth, Raymond, 1962. Book review of 'Maori Marriage: An Essay in Reconstruction'. American Anthropologist 64: 193-4.

Metge, Joan 1967. The Maoris of New Zealand. London: Routledge \& Kegan Paul.

Milroy, J. Wharehuia 2001. Expert evidence regarding tamariki whāngai in the case of an appeal by Waimania Hohua. The Maori Appellate Court of New Zealand, Waiariki District. Miniute Book: 10 APRO 49-51. Rotorua. 
Ngata, Apirana, n.d. [probably 1929]. The genealogical method as applied to early history of New Zealand. ATL qMS NGA. Alexander Turnbull Library, Wellington. (A copy also held in Special Collections mss 2 archives A-135, University of Auckland Library, Auckland).

O'Malley, Vincent, 1996. The Crown's Acquisition of the Waikaremoana Block 192125. Report WAI 894 A50. Waitangi Tribunal. Wellington.

Parsonson, Anne, 1980. The Expansion of a Competitive Society. A study in nineteenth-century Maori social history. New Zealand Journal of History 14: 45-60.

-1981. The Pursuit of Mana. In W.H. Oliver (ed.), The Oxford History of New Zealand. Wellington: Oxford University Press, pp. 519-41.

Salmond, Anne, 1976. Hui: A Study of Maori Ceremonial Gatherings. Auckland: Reed Methuen.

Sissons, Jeffrey, 2010. Building a house society: The reorganisation of Maori communities around meeting houses. Journal of the Royal Anthropological Institute (N.S.) 16: 372-86.

Stokes, E., Wharehuia Milroy, J., Melbourne, H. 1986. Te Urewera; Nga Iwi Te Whenua Te Ngahere; People, Land, and Forests of Te Urewera. Report WAI 894 A11. Waitangi Tribunal. Wellington. (original published by University of Waikato, Hamilton, New Zealand.)

Temara, Te Pou, 1993. Te Whenuanui (? -1907), Tuhoe chief, builder, and carver.

The Dictionary of New Zealand Biography. Te Ara - the Encyclopedia of New Zealand, http://www.TeAra.govt.nz/en/biographies/2t33/te-whenuanui (accessed 13 May 2017)

-2000. Hikawera Te Kurapa (1907-1985), Tuhoe tohunga, horse-breaker, farmer, Ringatu leader. Dictionary of New Zealand Biography. Te Ara - the Encyclopedia of New Zealand, http://www.TeAra.govt.nz/en/biographies/5t9/te-kurapahikawera (accessed 13 May 2017)

Te Urewera Act 2014 No 51, Public Act.

http://www.legislation.govt.nz/act/public/2014/0051/latest/DLM6183601.html

The Urewera District Native Reserve Act, 1896. New Zealand Statutes 1896, No 27. pp. $66-71$.

Tūhoe Claims Settlement Act 2014 No 50, Public Act. www.legislation.govt.nz/act/public/2014/0050/latest/DLM5481230.html

UMB 1. Urewera District Native Reserve Commission Minutebook 1. February 1899 March 1900. Smith, Butler, et al. In Maori. Archives New Zealand: (Wellington): Urewera MB 3, MLC 13, W3518, CD2, Vol.3; (Auckland): AREPRO 4711/1445.

UMB 5. Urewera District Native Reserve Commission Minutebook 5. March 1901 - May 1901. Butler, Scannell, et al. In English. Archives New Zealand: (Wellington): Urewera MB 5, MLC 13, W3518, CD 2, Vol.5; (Auckland): AREPRO 4711/1447.

Urewera Appellate Court MB 1. Urewera Appellate Court Minutebook 1. 191213. Jackson Palmer, Rawson. Archives New Zealand: (Wellington): Waiariki, Urewera Appelate MB 1, CD3518/2; (Auckland): AREPRO 4711/1450. 
Webster, Steven, 1975. Cognatic descent groups and the contemporary Maori: A preliminary reassessment. The Journal of the Polynesian Society 84(2): 121-152. 1998a. Maori hapu as a whole way of struggle: 1840s-50s before the Land Wars. Oceania 69(1): 4-35.

1998b. Patrons of Maori Culture; Power, Theory, and Ideology in the Maori Renaissance. Dunedin, New Zealand: University of Otago Press.

2002. Maori retribalization and treaty rights to the New Zealand fisheries. The Contemporary Pacific 14(2): 341-76.

2004. The Urewera Consolidation Scheme: Confrontations between Tuhoe and The Crown, 1915-1925. Wai 894 record of inquiry, doc D8. Waitangi Tribunal. Wellington, New Zealand.

2010. He kaawai hapuu Tuuhoe no te ao o mua: An ethnohistorical reconstruction of one hapuu branch of Ngai Tuuhoe in the Urewera District Native Reserve 1899-1903. Sites (N.S.) 7(1): 1-43.

2011. Do Maori know what a hapuu is? Journal of the Royal Anthropological Institute (N.S.) 17: 622-27.

2013. Are Maori hapu ‘houses'? Are whakapapa ‘strategic improvisations'? The ethnohistorical evidence from Ngai Tuuhoe. Sites (N.S.) 10(1): 30-50.

n.d.a. Urewera Land, 1895-1926: A Tentative Historical Survey of Government and Tuhoe Relations as Reflected in Offical Records. Unpublished manuscript 1984-5, Department of Anthropology. The University of Auckland Library.

n.d.b. He Mana Motuhake (Volume I): Ngāi Tühoe and the Urewera District Native Reserve 1894-1912. (Excerpts and some sources such as my index of Best 1898 are available from the author via $<$ swebster2@yahoo.com>.)

—n.d.c. He Mana Motuhake (Volume II): Ngāi Tūhoe and the Urewera District Native Reserve 1912-1926. (This is a revision of Webster 2004.)

Wolf, Eric, 1982. Europe and the People Without History. Berkeley: University of California Press.

1999. Envisioning Power: Ideologies of Dominance and Crisis. Berkeley: University of California Press.

\begin{abstract}
The large Urewera National Park of New Zealand, recently returned to control of the Tūhoe (and other Urewera) Māori, was originally established (1896-1907) as the Urewera District Native Reserve under their virtual home-rule. Discovery of extensive marriage alliances between clusters of Tūhoe hap $\bar{u}$ ' ancestral descent groups' involved in the 1899-1903 investigation raises the relationship between kinship and political economic power in the context of New Zealand colonisation. Guided by Eric Wolf's exploration of the kin-ordered mode of mobilising social labour, a detailed ethnohistorical study of the establishment of the reserve is reviewed here in terms of Tūhoe leaders' exercise of power in relation to one another, as well as the colonial government. In order to consider Wolf's conclusion that especially in the context of colonisation such leaders are likely to break through the bounds of their kinship
\end{abstract}


order, confrontations from 1900-1912 between several well-known Tūhoe leaders, an extensive marriage alliance, and three hapu are reviewed in some detail. It is hoped that an ethnohistory of this example of Tūhoe kinship and power at the turn of last century can complement the current resurgence of Tuhoe (and other Urewera) control over their original reserve.

Keywords: Māori kinship, political economy, Tūhoe, Urewera District, land claims ethnohistory, colonisation and resistance

\section{CITATION AND AUTHOR CONTACT DETAILS}

Webster, ${ }^{1}$ Steven, 2017. Māori kinship and power: Ngāi Tūhoe 1894-1912. Journal of the Polynesian Society 126(2): 145-180; DOI: http://dx.doi.org/10.15286/ jps.126.2.145-180

${ }^{1}$ Correspondence: 12 Trinity Street, Ponsonby, Auckland 1011, New Zealand. Email: swebster2@yahoo.com 